\title{
NOTE ON SEA TEMPERATURES IN THE ENGLISH CHANNEL, I92I TO I949, AND PLYMOUTH SUNSHINE AND LIGHT
}

\author{
By W. R. G. Atkins, F.R.S. and Pamela G. Jenkins \\ From the Plymouth Laboratory
}

(Text-figs. I-3)

International hydrographic station England no. I (E I) has been visited regularly for many years, and since I92I the periods have been (nominally) once a month, or more frequently. Much work has been done on the plankton and chemical changes in the water, but no biological use has been made of the temperature-depth observations, which are primarily of hydrographic importance. The aim of this paper is to render the sea-temperature observations over this long period readily available and to place beside them observations on air temperature, sunshine and light. Such comparisons may be expected to give information upon the causes of variations in temperature, but the adequate investigation of this very difficult problem is outside the scope of this note. The subject is worthy of fuller treatment on the lines suggested by Harvey (I925), based on data for the years I92I to I924, and has been considered on broad lines by Sverdrup, Johnson and Fleming (1942).

\section{The Sea-temperature Observations}

These are made with standardized thermometers in a Nansen-Petterssen water-bottle at $5 \mathrm{~m}$. intervals down to an almost constant reading, and thereafter at 10 or $20 \mathrm{~m}$. intervals to $70 \mathrm{~m}$. with the usual precautions. Surface samples are also taken with a wooden bucket, the bottle observations at the surface being termed $0.5 \mathrm{~m}$., but these two are here grouped together. Mean column temperatures are based on means for $2 \cdot 5,7 \cdot 5 \ldots 67 \cdot 5 \mathrm{~m}$. The observations are thus for single days, or possibly means for 2 or 3 days, in each month.

\section{The Air-temperature Observations}

These are got from the Meteorological Office publications. In I92I until the end of 1922 the figures for daily temperature taken were those of the Borough Meteorologist, which were based on observations at 9, I5 and 2I hr. The station is on the Hoe, close to the Marine Biological Laboratory, and is at about $30 \mathrm{~m}$. above sea-level. From January 1923 the Hoe records were based on mean values of the daily maximum and minimum readings taken at 
2I hr. Accordingly, we took those read at 7, I3 and I8 hr. at the Cattewater station, Mount Batten, which is about $22 \mathrm{~m}$. above sea-level. These continued until after the end of our 1938 period. For 1947 until August 1948 they were taken at Mount Wise, also about $22 \mathrm{~m}$. above sea-level, and from September I 948 till now they have been again at Mount Batten. Our postwar period means are based on observations at 3,9, I5 and $2 \mathrm{I} \mathrm{hr}$. The series is not therefore entirely concordant, though the resultant change is probably unimportant.

It is obvious that temperatures obtained, as monthly means, on land are not truly comparable with observations made over 20 miles to the south, at sea. But they are the only ones available and with the slower changes met with at sea as compared with on land, the less frequent readings at sea still give a tolerably accurate representation.

\section{The Sea and Air Temperatures}

The minimum sea temperature for the $2 \mathrm{I}$ years, $7 \cdot 4^{\circ} \mathrm{C}$, was on 27 February 1947, and the warmest winter minimum was in $1949,9.9^{\circ} \mathrm{C}$., on I3 April. Excluding the exceptional value for 1947 , ten winter minima lay between 8.2 and $9.0^{\circ} \mathrm{C}$., mean $8.55^{\circ} \mathrm{C}$, and ten between 9.0 and $9.9^{\circ} \mathrm{C}$., mean $9.4 \mathrm{I}^{\circ} \mathrm{C}$. The mean for the twenty is $8.98^{\circ} \mathrm{C}$. There was no indication of any regular movement in the value of the minimum temperature which occurred once in January, twice in February, sixteen times in March, once in April and once in December.

In winter, surface and column temperatures are almost identical. The column had become isothermal by October in I3 years, and was nearing this condition in eight Septembers. In I922, it was reached on or before II July and again by 22 September. The vertical mixing indicated is important in bringing up the nutrient salts.

The air temperature monthly mean minima were never in January, but nine occurred in February, four in March, one in November and seven in December, arranged quite irregularly.

The lowest maximum of the sea column was $13.12^{\circ} \mathrm{C}$., and 5 years were below $14.0^{\circ} \mathrm{C}$. Thirteen lay between $\mathrm{I} 4$ and $15^{\circ} \mathrm{C}$., three $15^{\circ} \mathrm{C}$. or over, with maximum $15.8^{\circ} \mathrm{C}$. The mean column maximum is $14.34^{\circ} \mathrm{C}$.

The maximum column temperatures occur when the column becomes isothermal or nearly so, usually late in September or early in October. The maximum surface temperature was observed fifteen times in August, four times in July and twice in September, such figures being influenced by the dates on which it was possible to make cruises. Mean monthly air maxima were twice in June, nine times each in July and August and once in September.

Table I shows the observations from which Fig. I has been constructed. Fig. 2 shows the mean temperatures of the water column at E I for selected years which include the warmest and the coldest. 
Fig. 3 shows the column maximum and minimum temperatures for each year. The greatest range was for $1947,7.02^{\circ} \mathrm{C}$., and the least, $4.32^{\circ} \mathrm{C}$., for I923. Out of the 2I years the order of difference was: I923, 2I; I925, 20; I922, I9; I924, I8; I926, I7; I927, I6, and in all these years the phosphate content of the water was relatively high.

Values for sunshine and light are also shown in Fig. 3.

\section{Table I. Comparison of Sea and Air Temperatures}

\begin{tabular}{|c|c|c|c|c|c|c|c|}
\hline & \multicolumn{3}{|c|}{ Air temp., ${ }^{\circ} \mathrm{C} .$, monthly mean } & \multicolumn{3}{|c|}{ Station E r, column temp., ${ }^{\circ} \mathrm{C}$. } & \multirow{2}{*}{$\begin{array}{l}\text { Station E I } \\
\text { Surface } \\
\text { max. }\end{array}$} \\
\hline & Coldest & Warmest & Mean & Coldest & Warmest & Mean & \\
\hline Jan. & $4 \cdot 2$ & $9 \cdot 5$ & $7 \cdot 3$ & $9 \cdot 0$ & $\mathrm{II} \cdot 3$ & $10 \cdot 2$ & II $\cdot 2$ \\
\hline Feb. & 0.9 & $8 \cdot 5$ & $6 \cdot 4$ & $7 \cdot 4$ & $10 \cdot 2$ & $9 \cdot 3$ & $10 \cdot 2$ \\
\hline Mar. & 5.9 & 9.5 & $7 \cdot 4$ & $8 \cdot 3$ & $10 \cdot 0$ & $9 \cdot 0$ & IO.I \\
\hline Apr. & $7 \cdot 9$ & I0.7 7 & 8.9 & $8 \cdot 2$ & $10 \cdot 0$ & $9 \cdot 4$ & $10 \cdot 6^{\star}$ \\
\hline May & $10 \cdot 5$ & 14.5 & $12 \cdot 0$ & $9 \cdot 25$ & II 4 & 10.4 & 13.5 \\
\hline June & I3. 8 & I 7.4 & I 4.9 & 10.5 & 12.4 & II. 5 & 15.7 \\
\hline July & I 4.7 & 19.9 & $16 \cdot 3$ & $12 \cdot I$ & 13.8 & I2.8 & I 8.4 \\
\hline Aug. & $14 \cdot 8$ & $19 \cdot 2$ & $16 \cdot 5$ & $12 \cdot 7$ & I4.5t & 13.6 & $19 \cdot 4 \ddagger$ \\
\hline Sept. & I3.I & $17 \cdot 0$ & I5: I & I2. 8 & 15.2 & 13.8 & 18.3 \\
\hline Oct. & 10.6 & I5.I & $\mathrm{I} 2 \cdot 2$ & I3. I & 15.8 & I3.8 & 16.4 \\
\hline Nov. & $5 \cdot 8$ & II $\cdot I$ & $9 \cdot 0$ & II 9 & 15.0 & 13.0 & 14.6 \\
\hline Dec. & 3.5 & 10.5 & $7 \cdot 4$ & 10.0 & I3. I & II 5 & 12.9 \\
\hline
\end{tabular}

* Surface II·2, 30 April I930.

+ Column temperature for 29 August 1947 was $15.3^{\circ} \mathrm{C}$. and the September and October maxima were for 1947 also. For I92I, October, November and December gave respectively $15.4,15^{\circ} \mathrm{O}$ and $13 . \mathrm{I}^{\circ} \mathrm{C}$.

¥29 August I949.

\section{Hours of Sunshine}

The values are those for Plymouth Hoe, as published by the Meteorological Office, in hours daily. The yearly means vary from 5.54 in 1949 , followed by 5.25 in $1929,5.17$ in I933, 5.13 in I92I, 5.00 in I948 to $4.03 \mathrm{hr}$. in I93I, other low values being $4 \cdot 16$ for $1927,4 \cdot 19$ for $1924,4 \cdot 21$ for 1947 , and $4 \cdot 25$ for both I937 and I938. The period covered was I92I-40 inclusive and I947-49. The mean value for 23 years is $4.63 \mathrm{hr}$. a day. It is obvious that the heat received from the sun is not linearly proportional to the hours of sunshine, since the intensity is influenced by solar altitude, which varies throughout both year and day.

\section{Illumination}

Since light falling on and penetrating the sea is absorbed and converted into heat, the illumination affects the temperature. What is measured is the daylight, from sun and sky, received on a horizontal surface on the laboratory roof in an almost unobstructed position. The photoelectric cell used is more sensitive to the short than to the long wave part of the spectrum, so that the effect of cloud in obscuring the sun is less than with a thermopile, which is approximately uniformly sensitive throughout the spectrum. The current is measured with a Cambridge thread-recorder galvanometer and the illumination is got from the area of the daily chart, in kilolux-hours, which for the 
year may be conveniently given in megalux-hours. The details of the measurements and results are given by Poole \& Atkins (1935, 1936), Atkins (1938),

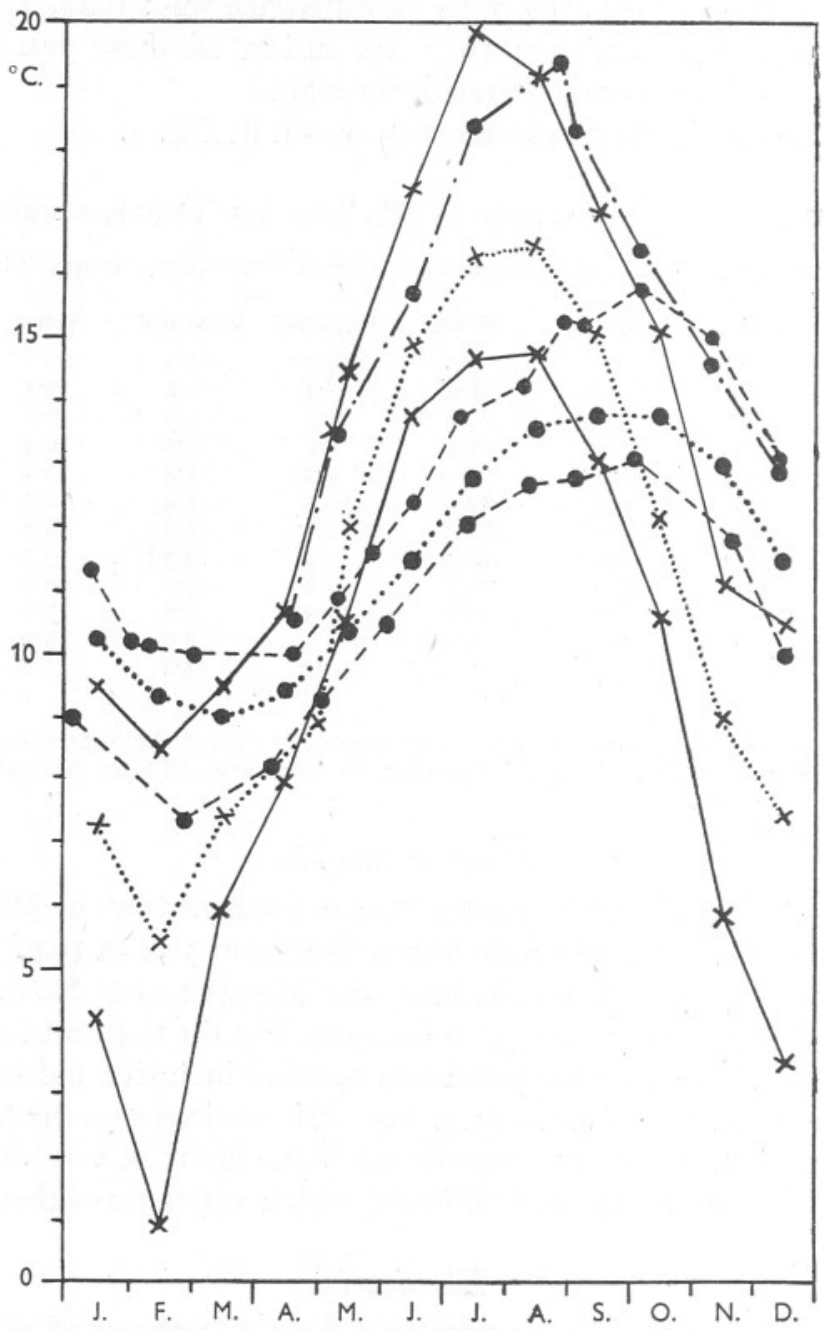

Fig. I. Air temperature at Plymouth, monthly means (crosses). The continuous lines show the warmest and coldest months of the period studied, plotted as if for single hot and cold years. The dots show the mean values. Sea temperatures at station E I (dark circles) are shown by broken lines for the water columns, warmest and coldest, as for air; the dots and dashes denote the warmest sea surface temperatures encountered each month. The dots show the mean values for the water column over the $2 \mathrm{I}$ years.

Atkins \& Ellison (1947), Atkins \& Jenkins (1952). The observations cover I4 years, I930-40 inclusive, also I947-49. The value for 1930 proved to be exceptionally high, I50 megalux-hours, but all efforts to show that this was 


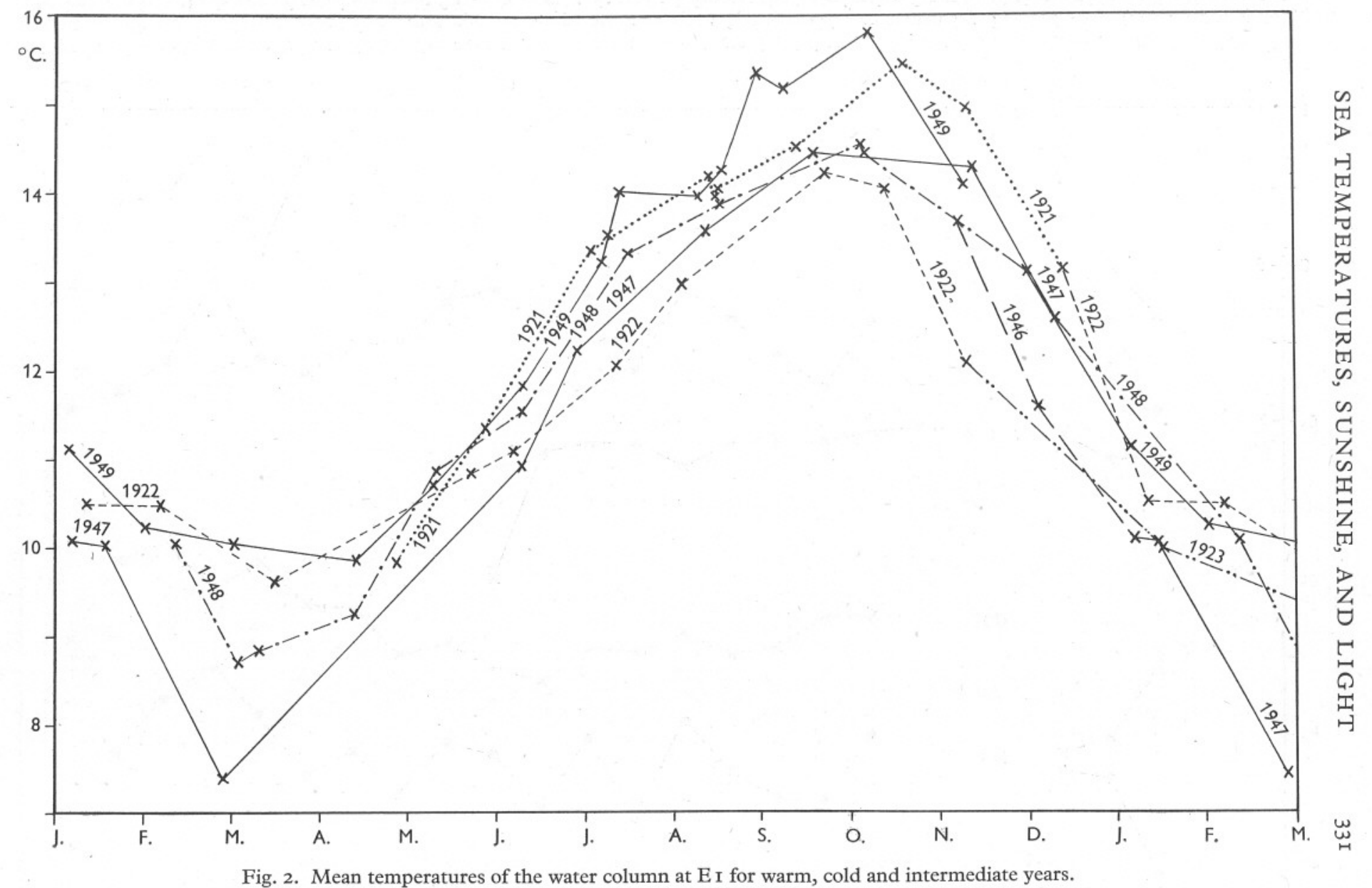




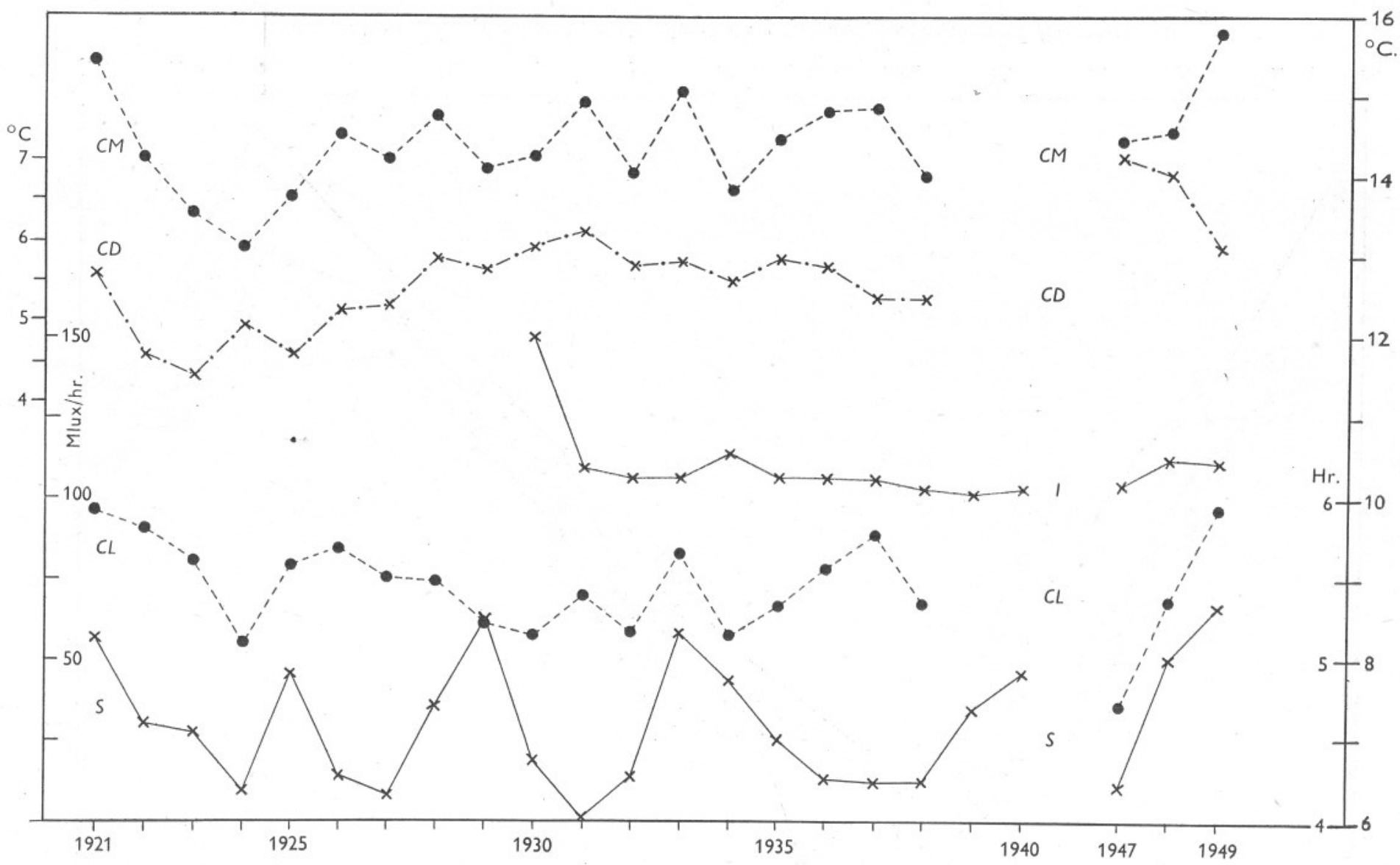

Fig. 3. The abscissae show years. The ordinates show the water column temperatures, from 6 to $16^{\circ} \mathrm{C}$., for the warmest month (broken line $C M$ ) and coldest month $(C L)$, of each year. The differences in temperature between $C M$ and $C L$ are shown by dot and dash $(C D)$, from 4 to $7^{\circ} \mathrm{C}$. The line $S$ gives the hours of sunshine daily for each year, 4-6; while $I$ denotes the illumination for each whole year in megalux-hours, 0-150. 
due to a subsequent loss of cell sensitivity have failed, and between highest and lowest values for daylight Aurén (1933, 1939) got a similar high range near Stockholm in a series between 1928 and I937. The minimum was in I939, with I03 megalux-hours and the I4-year mean is II6 megalux-hours.

\section{REFERENCES}

Atkins, W. R. G., I938. Photo-electric measurements of the seasonal variations in daylight around 0.4I $\mu$ from 1930 to 1937. Proc. Roy. Soc. A, Vol. I65, pp. 453-65.

Atrins, W. R. G. \& Ellison, M. A., I947. Photo-electric measurements of the seasonal variations in daylight at Plymouth, from I938 to March I94I compared with the years 1930 to I937. Proc. Roy. Soc. A, Vol. I9I, pp. 467-84.

Atkins, W. R. G. \& Jenkins, P. G., I952. Photo-electric measurements of the seasonal variations in daylight at Plymouth from 1947 to I949. Quart. Fourn. Roy. Met. Soc., Vol. 78, pp. 70-5.

Atkins, W. R. G. \& Poole, H. H., I936. The photo-electric measurement of the diurnal and seasonal variations in daylight and a globe integrating photometer. Phil. Trans. Roy. Soc. A, Vol. 235, pp. 245-72.

Aurén, T. E., I933. Illumination from sun and sky. Arkiv. Mat. Astron. Fysik, Bd. $24 \mathrm{~A}, 4$.

- 1939. Radiation climate in Scandinavian peninsula. Arkiv. Mat. Astron. Fysik, Bd. $26 \mathrm{~A}, 20$.

HaRveY, H. W., 1925. Evaporation and temperature changes in the English Channel. Fourn. Mar. Biol. Assoc., Vol. 13, pp. 678-92.

Poole, H. H. \& Atkins, W. R. G., I935. The standardization of photo-electric cells for the measurement of visible light. Phil. Trans. Roy. Soc. A, Vol. 235, pp. I-27.

SVerdrup, Johnson \& Fleming, 1942. The Oceans. New York. 